\title{
Late quaternary Neotectonic evolution of dun in Garhwal Sub Himalaya
}

\author{
VC Thakur*, AK Pandey and N Suresh \\ Wadia Institute of Himalayan Geology, Dehra Dun, INDIA \\ *To whom correspondence should be addressed.E-mail:bindu_ddn@sancharnet.in
}

Dehra Dun is $80 \mathrm{~km}$ long $20 \mathrm{~km}$ wide valley within the Siwalik foreland basin of Garhwal Sub-Himalaya, bounded by the frontal Siwalik range to its south and the Lesser Himalayan Mussoorie range to its north. The base of the Mussoorie range is demarcated by the Main Boundary Thrust (MBT) that brings the late Proterozoic-Cambrian sequence of Lesser Himalaya to override the Siwaliks. To the south a sudden topographic rise of the frontal Siwalik range from the alluvial plain marks the Himalayan Frontal Thrust (HFT) that separates tectonically the Siwalik Group strata from the Holocene to recent alluvial sediments. In his pioneering work, Nakata (1972) recognized four levels of geomorphic surfaces. In Dun the Siwalik Group strata are folded and eroded, and are overlain by 100-300 m thick Dun gravels. The post-Siwalik Dun gravels are lithostratigraphically classified into four units: Unit A, Unit B and Unit C in northern part and Unit D in southern part of Dun. Based on earlier published OSL dates (Singh et al. 2001), the assigned ages are: $>40$ Ka for Unit A, 29 Ka-22 Ka for Unit B and $10 \mathrm{Ka}$ and younger for Unit C.

In northern part of Dun the Siwalik Group strata are exposed in two different tectono-geomorphic framework: the dissected Siwalik and the pedimented Siwalik, the former has uplifted topography with isolated cover of Dun gravels whereas the later are exposed in entrenched stream sections overlain by thick cover of Dun gravels. The dissected and uplifted Siwalik constitutes the hanging-wall and the pedimented siwalik forms the foot-wall of the Santaurgarh Thrust (ST). The Unit A of Dun gravels, occurring as tilted beds dipping NE $15^{\circ}-45^{\circ}$ to horizontal and overlying the eroded and steeply dipping Siwalik, represent synorogenic deposition related to growth of the Santaurgarh anticline. The Santaurgarh anticline, an overturned fold, facing south with steeply to moderately dipping limbs was developed as fault-propagated fold over the ST. In the frontal Siwalik range Mohand anticline was developed as fault-bend fold over the HFT. The Mohand anticline is an upright and asymmetric fold with steep dipping forelimb and gentle dipping to horizontal back limb. On the range front the strath terraces occur at $\sim 20 \mathrm{~m}$ elevation, and the Siwalik strata dipping NE $30^{\circ}$ over the older alluvium are exposed in a trench. These observations indicate active displacement ongoing in Holocene time. South of the HFT, $\sim 15 \mathrm{~km}$ wide piedmont zone is uplifted to $10-15 \mathrm{~m}$ elevation as evidenced by remains of uplifted topography, entrenched streams and a topographic rise from flood plain towards the HFT. The uplift of piedmont zone is attributed to a blind fault emerging as imbricate of the southward propagating HFT. Based on earlier published OSL dates and our newly obtained OSL dates, age constraint is placed on the tectonic events. The HFT was initiated during interval between $500 \mathrm{ka}$ and $100 \mathrm{ka}$. The ST was initiated post- $500 \mathrm{ka}$ and continued its activity as young as post- $40 \mathrm{ka}$. The Bhauwala Thrust and Majhaun Fault were developed between $29 \mathrm{ka}$ and $22 \mathrm{ka}$, and the Asan Fault post-dated $10 \mathrm{ka}$. The upliftment of the piedmont zone post-dated $5 \mathrm{ka}$ and probably coseismic.

\section{References}

Nakata, T. 1972. Geomorphic history and crustal movements of the foothills of the Himalaya. Report of Tohoku University, Japan, 7th Series (Geography), 2, 39-177

Singh, AK, B Prakash, R Mahindra, JK Thomas and AK Singhvi. 2001. Quaternary alluvial fan sedimentation in the Dehradun valley piggy back basin, NW Himalaya: Tectonic and Paleoclimatic implications. Basin Res 13: 449-471 